Memórias de devoção e saberes

ancestrais

afrodiaspóricos: A

Irmandade de São

Benedito da Casa

Verde, São Paulo

(SP) ${ }^{1}$

\section{Memories of devotion}

and ancestral afro-

diasporic knowledge:

The Brotherhood of

St. Benedict of the

Green House, São

Paulo (SP)

\footnotetext{
${ }^{1}$ Este artigo integra parte da pesquisa que resultou na dissertação de mestrado (História Social) intitulada "Memórias afrodiaspóricas em território negro paulista: práticas ancestrais no Parque Peruche" (2018). O trabalho contou com o apoio de financiamento da Coordenadoria de Aperfeiçoamento de Pessoal de Nível Superior - Capes e do Conselho Nacional de Desenvolvimento Científico e Tecnológico - CNPq.
}

Bruno Garcia dos Santos Pontifícia Universidade Católica de São

Paulo (PUC-SP)

bruno.garciads@gmail.com

Amailton Magno Azevedo Pontifícia Universidade Católica de São

Paulo (PUC-SP)

amailtonazevedo@gmail.com

DOI: https://doi.org/10.22481/odeere.v3i6.4326

Resumo: Mesmo diante do violento processo de desterritorialização vivido pelas inúmeras comunidades africanas no contexto da dominação colonial europeia, práticas e saberes ancestrais foram ressignificados e reelaborados de forma a impregnar o tecido social das culturas negras das Américas. Nesta perspectiva, este artigo insere-se em um conjunto de reflexões que visam exaltar a importância da preservação de memórias afrodiaspóricas no Brasil. Para tanto, particularizase um território negro no município de São Paulo, o bairro da Casa Verde na zona norte da cidade. Com base na História oral e na pesquisa de campo, o objetivo central da presente pesquisa é sugerir possíveis traduções acerca da presença e permanência de ancestralidades negro-africanas na urbe paulistana a partir das narrativas compartilhadas e dos trabalhos de memória de Lucinda de Oliveira Marcelino. A colaboradora/narradora é filha de uma das fundadoras da Irmandade de São Benedito da Casa Verde, inaugurada em 1941. O acesso às memórias reconstruídas de Dona Lucinda permite sinalizar a presença de práticas ancestrais marcadas por cosmovisões herdadas e protagonizadas por 
mulheres. Tais concepções constroem identidades afirmadas que singularizam as experiências negras na metrópole, expressando valores civilizacionais e extraocidentais comunitários fundamentais à humanidade.

Palavras-chave: Casa Verde; Protagonismos femininos; Irmandades negras; Práticas ancestrais; Territórios afrodiaspóricos.

Abstract: Even in the face of the violent deterritorialization process experienced by numerous African communities within the context of the European colonial domination, ancestral practices and knowledge have been resignified and reformulated to pervade the fabric of society of Black cultures in the Americas. Hence, this article is part of a set of reflections aimed at praising the importance of preserving Afro-diasporic memories in Brazil. To do so, we focus on a black territory in the city of São Paulo, the Casa Verde neighborhood, located in the Northern Zone. Based on oral history and on fieldwork, our main objective is to suggest possible interpretations on the presence and permanence of Black-African ancestry in the São Paulo territory, considering the narratives and studies on memory shared by Lucinda de Oliveira Marcelino. The collaborator/narrator is the daughter of one of the founders of the São Benedito da Casa Verde Fraternity, which was founded in 1941. Evoking the reconstructed memories of Mrs. Lucinda allows indicating the presence of ancestral practices marked by women's protagonisms and inherited cosmovisions. Such conceptions create stated identities that particularize black experiences in the metropolis and express values of civilization, both communityrelated and in addition to those of the Western culture, which are paramount to humanity.

Keywords: Casa Verde neighborhood; Women's protagonisms; Black fraternities; Ancestral practices; $\quad$ Afro-diasporic territories.

\section{Introdução}

A modernidade ocidental construiu seus pilares sobre as terras do "Novo Mundo" com a exploração da força de trabalho de milhões de africanas(os) trazidas(os) à força para as Américas no contexto da dominação colonial europeia. No entanto, as forças vitais dos povos negros da diáspora abriram espaços, atuando nas brechas, nas fendas, nas fissuras do sistema escravocrata, se refazendo constantemente nos interstícios dos esquemas ocidentais.

Corpos negros puderam se (re)territorializar diante da trituradora máquina da opressão e do racismo ${ }^{2}$, adubando a terra com suas experiências, saberes, espiritualidades, cosmovisões e formas de luta. As sementes civilizacionais das populações negras, negligenciadas pelo pretencioso projeto hegemônico, germinaram em condições nada favoráveis e perpassaram as sociedades

\footnotetext{
${ }^{2}$ Enquanto forma sistemática de discriminação que tem a raça como fundamento, o racismo configura-se como uma tecnologia de poder da modernidade ocidental, operando de forma viscosa, ao atuar tanto no âmbito do privado quanto no âmbito público. Ao tratar da realidade brasileira, Munanga e Gomes assertam que "a perpetuação do preconceito racial em nosso país revela a existência de um sistema social racista que possui mecanismos para produzir as desigualdades raciais dentro da sociedade". A esse respeito, ver: MUNANGA, K.; GOMES, N. L. O negro no Brasil de hoje. São Paulo: Global, 2006, p. 182.
} 
dominantes com seus movimentos e táticas ${ }^{3}$ policêntricas por onde um universo de culturas ancestrais heterogêneas impregnou e perpetuou a presença africana nas Américas.

Em termos visuais e filosóficos, as civilizações africanas:

[...] não eram somente impressionantes por sua densidade urbana, seu refinamento e complexidade, mas também empodeiradas por um ímpeto interno de convicção e de postura que as deslanchou no mundo, dominando e vencendo acidentes de classe, de status e de opressão política. A ascensão, o desenvolvimento e as realizações da arte e da filosofia ioruba, kongo, fon, mande e ejagham se fundiram com novos elementos ultramarinos, modelando e formando a tradição visual negra atlântica ${ }^{4}$.

Com relação ao contexto afrodiaspórico, uma gama de possibilidades revelada pela expressividade das cosmovisões extraocidentais constitui a memória e a continuidade de práticas ancestrais herdadas e reinventadas por negras(os) nas Américas. Essas práticas conjugam elementos que só podem ser apreendidos por meio de prismas de análise não cartesianos ${ }^{5}$. Se socialmente elas emergem em culturas ditas periféricas, simbolicamente elas ocupam uma posição central, posto que ao integrarem um patrimônio sensível diversificado, tais práticas se estendem em expressões artísticas, filosóficas, políticas e cosmológicas.

E como bem indica Antonacci, as heranças culturais de povos africanos na diáspora vêm sendo concretizadas:

[...] em experiências, sensações, intuições, emoções de seus próprios corpos e mentes, comunitariamente socializados e educados na equivalência de todos os

\footnotetext{
${ }^{3}$ Ao contrário do que sugere a noção de estratégia, circunscrita a um lugar próprio e capaz de servir de base a uma racionalidade específica, as táticas atuam pelas brechas do sistema, jogando com os acontecimentos para os transformar em ocasiões. Nesse sentido, o termo é pensado a partir do que propõe Certeau quando afirma: "as táticas manifestam igualmente a que ponto a inteligência é indissociável dos combates e dos prazeres cotidianos que articula, ao passo que as estratégias escondem sob cálculos objetivos a sua relação com o poder que os sustenta, guardado pelo lugar próprio ou pela instituição". Cf. CERTEAU, M. de. A invenção do cotidiano: 1. Artes de fazer. Petrópolis: Vozes, 1994, p. 47.

${ }^{4}$ THOMPSON, R. F. Flash of the spirit: arte e filosofia africana e afro-americana. São Paulo: Museu Afro Brasil, 2011, p. 17.

${ }_{5}^{5}$ Este termo refere-se ao pensamento inaugurado por René Descartes (1596-1650), fundador da filosofia ocidental moderna, no século XVII. Segundo Descartes, a centralidade do pensamento teocrático difundido na Europa da Idade Média fora substituída pela visão que privilegia o Homem (ocidental) dos tempos modernos. Este, por sua vez, é concebido a partir de uma noção de verdade universal sobre a qual o acesso às leis do universo e a capacidade de produzir conhecimento e teorias científicas lhes são próprios. Nessa perspectiva, o ego-cogito cartesiano ("Penso, logo existo") é o fundamento das ciências modernas ocidentais e das filosofias eurocentradas. Ao estabelecer um dualismo entre mente e corpo e entre mente e natureza, Descartes proclamou um conhecimento não-situado e dito universal. Apoiado em lógicas cartesianas, o homem ocidental (masculino e branco) representa seu conhecimento como o único capaz de alcançar uma consciência universal, negligenciando o potencial e a complexidade dos conhecimentos extraocidentais.
} 
sentidos, com memória e inteligência plasticamente esculpidas em gestos, ritmos, rituais, metáforas e jogos mentais, resguardando e atualizando seus cosmos ${ }^{6}$.

Diante de tais considerações e ao particularizar as linguagens, os valores e os saberes de afrodescendentes do Brasil, é possível constatar que, enquanto ciência, tais práticas traduzem cosmovisões que dão sentido às experiências de suas/seus protagonistas, além de atuarem como formas de resistências negociadas ou não.

As cosmovisões, em contexto diaspórico, se manifestam em muitas esferas da experiência negra nas Américas: são os tecidos, as músicas, os rituais, os cantos, a oralidade, a estética, os símbolos, os cultos às(aos) ancestrais, etc. Tudo se combina de forma que arte, religião e vida apresentam-se como polos interligados da existência.

O intercambio de culturas e das comunidades de África no Brasil produziram ineditismos que particularizam suas práticas ancestrais. Mesmo diante às tensões e aos conflitos, a multiplicidade de valores civilizacionais advindos do continente africano foi possibilitada por encontros profundos por onde se refizeram culturas e visões de mundo. A solidariedade dos povos da diáspora gerara um egbé ${ }^{7}$ ou comunidade-terreiro que, nas palavras de Sodré:

É repositório e núcleo reinterpretativo de um patrimônio simbólico explicitado em mitos, ritos, valores, crenças, formas de poder, culinária, técnicas corporais, saberes, cânticos, ludismos, língua litúrgica e outras práticas sempre suscetíveis de recriação histórica, capazes de implementar um laço atrativo de natureza intercultural (negros de etnias diferentes) e transcultural (negros com brancos) ${ }^{8}$.

A partir daí registros culturais afrodiaspóricos podem ser apreendidos por meio do acesso às práticas ancestrais revigoradas que impregnaram o tecido social de culturas negras no Brasil. Em São Paulo, as irmandades, as umbandas, as quimbandas, os candomblés ketu e Angola-Congo expressam pelas permanências de seus signos, ritmos e práticas um conjunto de mundos e de Áfricas que se ressignificam e dão outros sentidos à cidade. É preciso referenciar e reverenciar tais experiências, pois dos intestinos da terra-ilè emergem memórias ancestrais que irrompem os horizontes apontando para novas perspectivas.

\footnotetext{
${ }^{6}$ ANTONACCI, M. A. Memórias ancoradas em corpos negros. São Paulo: EDUC, 2014, p. 265.

7 Em língua ioruba, segundo Ribeiro e Sàlámì, Egbę pode significar companhia, reunião, partido, grupo, festa, sociedade, corporação, fraternidade, comunidade. O termo também pode representar uma divindade plural, EgbęAráagbó, designando ao mesmo tempo um orixá e uma corporação de seres espirituais. Cf. RIBEIRO, R. İ.; SÁLẦMÌ S. (King). Exu e a ordem do Universo. 2a. ed. São Paulo: Oduduwa, 2015, p. 426.

${ }^{8}$ SODRE, M. Claros e Escuros: identidade, povo e mídia no Brasil. 3a ed. Petrópolis: Vozes, 2015, p. 195-196.
} 


\section{Zona norte: terreiro negro paulistano}

[...] E também, já naquela época, eu entoava cantos de louvor a todas nossas ancestrais, que desde a África vinham arando a terra da vida com as suas próprias mãos, palavras e sangue?.

O texto acima reproduz um excerto do conto Olhos d'Água, escrito por Conceição Evaristo. São palavras entretecidas por uma mulher negra que suscitam reflexões potenciais sobre um carregar-se no comunitário. Tal excerto conjuga tempos e espaços distintos que se cruzam na medida em que relações se refazem e se (re)significam no Atlântico Negro ${ }^{10}$. Ancestrais que araram a terra da vida com suas próprias mãos, semeando palavras e fertilizando os solos com o sangue de suas lutas, pela sobrevivência de suas/seus descendentes e de suas culturas. São corpos que marcaram os lugares pelos quais passaram e que, mesmo diante do reconhecimento das perdas, resguardaram modos de sentir e transgredir, cultivando seus saberes e suas ciências.

Assim constitui-se a vibração cultural nas Américas: pelo modo com o qual as(os) africanas(os) e suas/seus descendentes se estabeleceram e recriaram suas próprias realidades em contexto diaspórico.

Nesse sentido, para que territorialidades negras sejam pensadas no entrelaçamento de culturas presentes na constituição da urbe paulistana, cabe precisar a noção atribuída ao termo território. O espaço aqui é concebido a partir da ação humana, enquanto lugar por onde se engendram movimentos, por onde se deixam marcas, memórias, rastros, formas de ser e estar no mundo. Ao pensar que as relações estabelecidas entre os sujeitos se constituem espacialmente e se configuram enquanto processos de subjetivação individual e comunitária, a ideia de território aparece nesta perspectiva como espaço real vivido, tecido e marcado por experiências múltiplas. Consoante à essa perspectiva, Santos completa:

O território não é apenas o conjunto dos sistemas naturais e de sistemas de coisas superpostas. $O$ território tem que ser entendido como o território usado, não o território em si. O território usado é o chão mais a identidade. A identidade é o sentimento de pertencer àquilo que nos pertence. $O$ território é o fundamento do trabalho, o lugar da residência, das trocas materiais e espirituais e do exercício da vida ${ }^{11}$.

\footnotetext{
${ }^{9}$ EVARISTO, C. Olhos d'Água. Rio de Janeiro: Pallas, Fundação Biblioteca Nacional, 2016, p. 18.

${ }_{10}$ Segundo Paul Gilroy, o Atlântico Negro configura-se enquanto espaço transversal por onde confluem uma geopolítica e uma geocultura negra; bem como uma contranarrativa à modernidade europeia. Cf. GILROY, P. $O$ Atlântico Negro: modernidade e dupla consciência. São Paulo: Editora 34; Rio de Janeiro: Universidade Cândido Mendes; Centro de Estudos Afro-Asiáticos, 2001.

${ }^{11}$ SANTOS, M. O dinheiro e o território. GEOgraphia, Rio de Janeiro, ano 1, n. 1, p. 7-13, 1999, p. 8.
} 
Tais reflexões nos permitem então conceber a cidade para além de suas relações puramente funcionais. A esse respeito, Rolnik disserta:

Então, uma rua, para além de ser um lugar onde se passa ou se deixa de passar, uma rua está carregada de história, está carregada de memória, está carregada de experiências que o sujeito teve, que seu grupo teve e que a história de seu grupo naquele espaço teve ${ }^{12}$.

A rua, sob tal perspectiva, configura-se também nas palavras de Sodré como um "lugar de indeterminações, em espaço de proximidade entre vida cotidiana e produção simbólica, lugar de uma atmosfera emocional ou afetiva que institui canais não linguísticos de comunicação ${ }^{13 \prime}$. É por isso que, segundo o mesmo autor, o território torna-se "continente de uma densidade simbólica, assimilável sinestesicamente, com corpo e espírito integrados numa atenção participante ${ }^{14 \prime \prime}$.

Ao particularizar as experiências paulistanas, torna-se oportuno investigar alguns pormenores que caracterizam o universo da zona norte de São Paulo, território marcado por forte presença negra que continua impregnando o tecido social brasileiro.

Situada ao norte do rio Tietê, a zona norte constitui uma região sobre a qual repertórios culturais negros se concentram e se afirmam. Em sua cartografia disforme, entre colinas que se estendem a partir do fluxo dos veios da terra, a região engloba inúmeros distritos, sendo eles: Freguesia do Ó, Brasilândia, Pirituba, Perus, Santana, Tucuruvi, Casa Verde, Cachoeirinha, Vila Maria, Vila Guilherme, Vila Medeiros, São Domingos, Jaraguá, Anhanguera, Limão, Mandaqui, Jaçanã e Tremembé.

Rolnik ao tratar da dimensão racial da segregação socioespacial brasileira, ressalta o fato de haver em São Paulo um eixo de expansão além Tietê que se inicia na Casa Verde/Limão e se estende "na direção dos morros periféricos, conformando uma rede de lugares de cultura, religião e socialização afro-brasileiras ${ }^{15}$ ". Mesmo diante dessa forte segregação étnico-racial ${ }^{16}$, posto que a

\footnotetext{
${ }^{12}$ ROLNIK, R. História urbana: História na cidade? In: FERNANDES, A.; GOMES, M. A. A. F. Cidade e história. Salvador: UFBA/ Faculdade de Arquitetura. Mestrado em Arquitetura e Urbanismo: Anpur, 1992, p. 28.

${ }^{13}$ SODRÉ, M. O terreiro e a cidade: a forma social negro-brasileira. Petrópolis: Vozes, 1988, p.146.

${ }^{14}$ Ibid., p. 146.

${ }^{15}$ ROLNIK, R. Negros na cidade de São Paulo: presença invisível ou incômoda? Blog da Raquel Rolnik. 2017. Disponível em: $\leq$ https://raquelrolnik.wordpress.com/2017/11/16/ negros-na-cidade-de-sao-paulo-presenca-invisivel-ouincomoda/ $>$. Acesso em: $20 \mathrm{dez} .2017$.

${ }^{16} \mathrm{Em}$ termos mais precisos, Rolnik apresenta o quanto a distribuição de negras(os) em São Paulo é desigual e não arbitrária. Ao considerar todos os distritos da cidade, a autora confere que "a Brasilândia ocupa a $14^{\mathrm{a}}$ posição na escala que mede a presença negra no território, agora liderada pelo Jardim Ângela, com $60 \%$ de população afrodescendente, seguido pelo Grajaú (56,8\%). Esses bairros se localizam na periferia da Zona Sul, mas os negros são mais de 50\% em todas as periferias da cidade, especialmente na Zona Norte e Leste. Por outro lado, em Moema, um dos bairros nobres
} 
presença negra é, na maioria das vezes, ínfima nos bairros nobres de São Paulo, mananciais de culturas negras transmutam os lugares, consolidando na cidade espaços de emancipação.

Diante de tal cartografia desigual, é preciso identificar elementos que conceberam São Paulo para além daquilo que se configurava enquanto projeto hegemônico de cidade e memória. Pautando-se em reflexões extraocidentais, Silva atenta para a necessidade de enegrecer ${ }^{17}$ a memória da cidade e Azevedo apresenta, de forma inédita as micro-áfricas ${ }^{18}$ que imprimiram suas marcas no processo de industrialização e urbanização paulistana. Segundo o autor: "essas microáfricas podem ser compreendidas como vivências dissonantes que desobedeceram a certos limites estabelecidos do que deveria ser a cidade, para construir e operar outras cidades e outras memórias $^{19 \prime \prime}$.

Assim, recorrer às histórias de vida pode ser um caminho interessante para que memórias subterrâneas possam inundar ruas e calçadas a fim de que outras cidades e outras(os) agentes sócio-históricas(os) sejam reconhecidas(os).

A metáfora do terreiro ${ }^{20}$ cunhada por Sodré parece corroborar para o sentido pelo qual se constitui a forma social da(o) negra(o) brasileira(o) no espaço urbano: o terreiro enquanto território carregado de subjetividades negras, enquanto resistência das marcas simbólicas (re)elaboradas e ressignificadas cotidianamente, enquanto território por onde se entrelaçam formas novas de sociabilidade com marcas específicas de corpos afrodescendentes.

Ao particularizar a experiência de famílias negras na urbe paulistana, no encontro-diálogo com as(os) moradoras(es) do bairro da Casa Verde, na zona norte do município de São Paulo, foi possível captar a presença de protagonismos femininos no que se refere às memórias de práticas ancestrais herdadas e reelaboradas. Muitas mulheres negras do bairro atuaram de diversas formas para a permanência de cosmovisões extraocidentais, marcando a presença de africanidades em São Paulo, ao norte do rio Tietê. Tais memórias femininas irrompem novidades sob o ponto de vista sócio-histórico, posto que promovem uma ruptura com a normatividade, e portanto, atuam de forma a reposicionar o poder e as relações de gênero.

da cidade, a presença negra não chega a $6 \%$, proporção muito próxima às do Itaim Bibi e do Alto de Pinheiros”. Cf. Ibid.

17 SILVA, S. A. G. da. Negros em Guaianases: cultura e memória. 145 f. Dissertação (Mestrado em História) Pontifícia Universidade Católica de São Paulo, Departamento de História, São Paulo, 2015.

${ }^{18}$ Ao cunhar tal conceito, Azevedo explica as vivências e memórias negro-mestiças em São Paulo. Cf. AZEVEDO, A. M. A memória musical de Geraldo Filme: os sambas e as micro-áfricas em São Paulo. 224 f. Tese (Doutorado em História) - Pontifícia Universidade Católica de São Paulo (PUC), Departamento de História, São Paulo, 2006.

${ }^{19}$ Ibid., p. 25.

${ }^{20}$ SODRÉ, op. cit., p. $53-53$. 


\section{Memórias de devoção ancoradas por ancestralidades}

Não há fronteiras para os trabalhos da memória, já que esta se dilata por meio da dialética entre esquecimento e lembrança, fazendo emergir histórias subterrâneas a partir das reflexões e acepções do presente. Recorrer à memória como recurso metodológico permite "não apenas lidar com a dimensão subjetiva do vivido, como também com as teias de significação que urdem as vidas dos sujeitos ${ }^{21 "}$.

Na antiga rua Galileia, subdistrito da Casa Verde Média, memórias de devoção podem ser acessadas, tendo em vista a atuação central de Lucinda de Oliveira Marcelino, representante e herdeira das atividades da Irmandade Negra de São Benedito.

Dona Lucinda, mulher negra de 80 anos, nascida em 1937 no bairro das Perdizes, zona oeste do município, compartilha de sua experiência enquanto filha de uma das fundadoras da Irmandade de São Benedito da Casa Verde, entidade católica constituída por negras(os) da região da Zona Norte de São Paulo.

Os encontros com a colaboradora da pesquisa se deram de forma particular, pois os portais da memória acessados por Dona Lucinda foram as fotografias, documentos preciosos pelos quais inúmeras histórias puderam se entrecruzar. A partilha se configurou por meio de memórias espirais, repletas de descontinuidades, repetições, revisões, digressões, em um trabalho sinuoso de reconstrução do passado que escapa à lógica linear e progressiva das concepções de tempo da modernidade ocidental. Os signos que constituem as fotografias trouxeram à tona lembranças das(os) antigas(os), dos afetos, dos sambas, dos bailes, das festas, dos cortejos, dos momentos de devoção, dos trabalhos junto à comunidade, das perdas e das rupturas. A sala de sua casa inundou-se de histórias negras impregnadas de ancestralidade. Com a palavra, Lucinda!

Eu nasci nas Perdizes e minha mãe contava que a gente morava em uma vila com bastante casas lá na Cardoso de Almeida. Eu tinha 1 ano quando meu pai comprou esse terreno, eu era pequenininha. E aqui era só mato. Ele trabalhava no armazém da Sorocabana ${ }^{22}$ e ele comprou aqui. A casa não era assim, só tinha um quarto, essa sala e a cozinha, e minha mãe contava que aqui era de terra e que eu tinha medo, pavor de ficar no chão, na terra [risos]. O único que nasceu aqui na Casa Verde foi meu irmão caçula, o Rubinho, que já faleceu. Até lá embaixo é tudo família. O meu pai comprou tudinho aqui até lá embaixo. Tem aqui minha casa, em cima quem mora é a minha sobrinha, um sobrado que tem aí descendo a

\footnotetext{
${ }^{21}$ BERNARDO, T. Memória em branco e negro: olhares sobre São Paulo. São Paulo: EDUC; Fundação Editora da UNESP, 1998, p. 29-30.

${ }^{22}$ O pai de Dona Lucinda, Pedro de Oliveira (1911-1968), era ferroviário e trabalhava na Companhia Estrada de Ferro Sorocabana (1875-1971). Atuou também como cuiqueiro da Escola de Samba Unidos do Peruche.
} 
escada é a casa da minha cunhada que casou com o meu irmão. E nos fundos, tem outra casa onde mora a minha sobrinha, a filha do meu irmão caçula. E aí a minha irmã fez esse sobrado que tem aí do lado, só que a entrada é por lá. Aqui, hoje mora meus filhos, genros, meus netos e bisnetos, tudo comigo, tudo aqui.

A minha mãe foi uma das fundadoras da Irmandade de São Benedito, ela era muito católica e ia muito na Igreja Nossa Senhora das Dores, uma travessa ali da Avenida Casa Verde, aí fundaram a irmandade. O seu Cilino também foi um dos fundadores e morava aqui perto, aqui na rua Galileia, ele e mais outros vieram buscar minha mãe que tinha muito conhecimento e era muito conhecida. Minha mãe também foi uma das fundadoras da Igreja de São Benedito e de São Francisco de Paula do Peruche, e foi ela quem levou a Irmandade de São Benedito pra lá. Depois o pessoal foi morrendo, aí acabou a irmandade lá, só tem aqui. [...] Eu fiz minha primeira comunhão com nove anos, aí minha mãe pôs eu na Irmandade, $e$ já entrei na Irmandade e tô até hoje. Os fundadores, no dia do aniversário da irmandade, cada um pegava um pouco de gente que vinha de fora assistir a festa e levava pra sua casa, e minha mãe também trazia o povo dela. Tinha também o salão da igreja e um cinema que recebia as pessoas. Quando o cinema fechou, aí minha mãe disse assim ó: não, eu vou continuar servindo na minha casa. Aí minha mãe continuou aqui e toda vez que ela fazia a festa pra São Benedito, o pessoal ao invés de ir na igreja, vinha tudo pra cá, porque fechava a rua né, e naquele tempo nem precisava ficar mandando fechar a rua, o pessoal vinha tudo pra cá ficar e almoçar.

Minhas tias tudo, vinha aqui ajudar e quando minha mãe faleceu a gente falou: não vamos parar com o almoço da sua mãe, nós vamos continuar. Aí minhas tias, minha família inteira, quando chegava o segundo domingo de janeiro, o pessoal vinha tudo pra cá almoçar. Aqui era até rua de terra quando minha mãe organizava a festa. Faz mais de quarenta anos que eu faço esse almoço, e não parei até hoje. E até hoje eu fecho a rua, vou na subprefeitura, na CET, vou na delegacia pra pedir policiamento, tudo. E vem gente de fora, de São Paulo e do Rio de Janeiro. Aqui funciona assim, tem o almoço né que todo mundo vem comer aqui, né Luzia? [em referência à filha, também presente]. E sabe o que tem aqui também? Tem o pagode, o pessoal gosta do pagode [risos], aí eles tocam músicas bem enfezada de samba [expressão de entusiasmo] e meu almoço é servido tudo na rua. O Calvo me ajudou bastante com o fechamento da rua pro almoço, tá aí os papel, ele levou lá pra Câmara Municipal ${ }^{23}$ para se tornar oficial, pra quando alguém achar ruim, tá aí o papel.

Ao inaugurar sua narrativa se situando no tempo e no espaço, Dona Lucinda reconstrói seu passado evocando a presença das (os) suas/seus ancestrais e convidando suas/seus interlocutoras(es) à adentrar no universo de suas memórias. Segundo Benjamin, "quem ouve uma

\footnotetext{
${ }^{23}$ De acordo com a lei no 13.904 de 2004, implementada pelo vereador Rubens Calvo (PT), a Festa de São Benedito da Casa Verde foi incluída no calendário oficial da cidade de São Paulo (SP).
} 
história está na companhia do narrador, mesmo quem lê, participa dessa companhia ${ }^{24 ” .}$

Quando faz emergir suas lembranças, a colaboradora da pesquisa parece apresentar elementos que se traduzem em valores herdados de sociedades africanas e afrodiaspóricas, como, por exemplo, a concepção de família e a relação desta com o espaço.

Dona Lucinda indica por meio de gestos e da fala os diferentes espaços pelos quais se estendem e se localizam suas/seus familiares. O terreno comprado por seu pai conecta em diferentes núcleos as(os) integrantes da família e o espaço é frequentemente moldado conforme um novo membro passa a compor o seio familiar. Um conceito de família bem mais abrangente configura essa realidade social e não pode ser apreendido por meio de classificações estruturalistas que conceberam os modelos de família nuclear. Tal particularidade pode ser explicada como um valor centro africano, herdado e reelaborado por famílias negras no contexto da diáspora. A esse respeito, Savieto completa, ao tratar da presença centro africana na região do Vale do Paraíba (SP):

A grande família é um valor para o centro africano. É nela que convivem as diversas temporalidades, os ancestrais em contato com seus descendentes, as novas gerações que possibilitam o reviver das antigas gerações nos cultos e na perpetuação das memórias ${ }^{25}$.

O espaço habitado, nesse sentido, é concebido de forma complexa e mutável, e a noção de comunidade muito associada à família alargada prevalece, de modo que a ideia do "eu", chave central da filosofia ocidental moderna, só pode ser entendida a partir de uma participação solidária. Assim, de acordo com Altuna, quando discute a ética da vida em sociedades bantu ${ }^{26}$ : “Não existe vida comunitária sem vida individual solidária, ativa e responsável, e não pode existir vida individual sem comunidade ${ }^{27 \prime \prime}$.

É importante ressaltar aqui que a realidade pela qual se encontram as famílias negras brasileiras também é mediada por outros fatores, sobretudo diante da difícil situação imposta às(aos) afrodescendentes no País. Portanto, elementos aqui sinalizados como permanências e reelaborações de Áfricas entre negras(os) na diáspora devem ser analisados tendo em vista todo o

\footnotetext{
${ }^{24}$ LOWY, M. O Narrador, In: BENJAMIN, Walter; HORKHEIMER, M.; ADORNO, T. W.; HABERMAS, J. Os pensadores. São Paulo: Abril cultural, 1980, p. 68.

25 SAVIETO, M. C. Catolicismos crioulizados: presença centro africana na região do Vale do Paraíba (SP). 118f. Dissertação (Mestrado em História) - Pontifícia Universidade Católica de São Paulo, Departamento de História, São Paulo, 2010, p. 40.

${ }^{26}$ Aqui, é válido ressaltar que o uso do termo bantu se refere ao tronco linguístico que compreende inúmeros povos e culturas da África central.

${ }^{27}$ ALTUNA, R. R. de A. Cultura Tradicional Bantu. Luanda: Paulinas, 2014, p. 502.
} 
processo de exclusão socioespacial e racial que marca profundamente tais segmentos da população.

Segundo Dona Lucinda, sua mãe Luzia Barbosa de Oliveira nascera em Bananal, no Vale do Paraíba, município do estado de São Paulo, em 27 de setembro de 1912. A mãe mudou-se para a cidade de São Paulo com a família onde conheceu Pedro de Oliveira. Eles se casaram em 1934 e tiveram quatro filhos: Lucinda, Alice, Moacir e Rubens. Sempre muito devota de Nossa Senhora Aparecida e de São Benedito, a mãe de Lucinda dedicou-se ao trabalho religioso e por seu conhecimento e popularidade, fundou, em 1941, a Irmandade de São Benedito da Casa Verde, entidade católica formada por famílias negras das comunidades da Casa Verde e do Parque Peruche. Desde então a irmandade atuou de diversas formas, tendo em vista o vínculo com a Paróquia de Nossa Senhora das Dores, na mesma região.

Lucinda relata que, em todo segundo domingo do mês de janeiro, os membros da Irmandade organizavam em suas próprias residências um almoço de acolhida às(aos) devotas(os) de São Benedito durante o aniversário da Irmandade. Em vista da morte de sua mãe, Lucinda decide, por intermédio e apoio de sua família, prosseguir com essa atividade junto à irmandade, na tentativa de atuar em prol da preservação das sociabilidades comunitárias, continuando um projeto iniciado pelas(os) suas/seus ancestrais. Aqui, a herança simbólica deixada por Dona Luzia passa para a filha, que se dedica à irmandade de forma a manter viva a presença e memória de sua mãe. Dona Lucinda, portanto, se tornou guardiã das memórias das(os) suas/seus, mantenedora de uma tradição viva compartilhada há 77 anos por negras(os) na metrópole.

É interessante perceber que ao organizarem a festa em homenagem à São Benedito, os membros da Irmandade, em particular Dona Lucinda e família, reatualizam um ritual de celebração que se desenvolve há séculos, revelando por meio da festa uma presença física e cultural dos grupos afrodescendentes na sociedade.

A colaboradora destaca que a festa compreende em acolher e partilhar de uma grande refeição em homenagem ao santo patrono das(os) negras(os), dos cafezais e muito associado à cozinha e à alimentação, já que fora cozinheiro antes de ser canonizado. Portanto, Dona Lucinda organiza tudo para que as(os) devotas(os) sejam bem recebidas(os), possam tomar um bom café da manhã e, também, desfrutar do grande banquete, um almoço servido à comunidade que se reúne na rua Galileia.

De acordo com Dona Lucinda e sua filha, o almoço é acompanhado de grandes festejos, 
muita dança e muita música, tudo para assegurar o bem viver ${ }^{28}$ da comunidade e agradecer, em nome da Irmandade, as dádivas concebidas por São Benedito. A festa, por seu "caráter regenerador", é um "momento de máxima exaltação e excessos fecundos, muita comida, muita dança, muita alegria ${ }^{29 \prime \prime}$.

Tais concepções comunitárias evocam tanto a vida quanto a morte, já que as(os) antigas(os) são reverenciadas(os) e as novas gerações são integradas nessa prática ancestral. Além disso, essas formas lúdicas e sagradas de celebrar apontam para visões de mundo que atualizam cosmovisões euro-cristãs e africanas no contexto da diáspora.

Mesmo se tratando de fontes primárias inesgotáveis de conhecimento sobre o imaginário coletivo cristão, posto que se configuram como entidades católicas, as irmandades brasileiras devem ser estudadas à contrapelo ${ }^{30}$, pois, como bem menciona Santos, esses estudos:

Muito embora na forma todos eles sejam respeitosos à teologia e ao direito canônico, requisito indispensável para a sua aprovação, na essência escondem práticas destoantes do catolicismo doutrinal ${ }^{31}$.

Em termos históricos, as irmandades puderam preservar, ao longo dos séculos, grande parte dos valores civilizacionais negro-africanos, representados sob a forma de elementos culturais que foram transportados para o "Novo Mundo", e em particular ao Brasil, na vigência do sistema escravocrata. Ainda segundo Santos, tais valores foram "recriados através de novas experiências históricas assinalando e preservando diferenças conceituais frente a cultura

\footnotetext{
${ }^{28}$ Ao inspirar-se pelas cosmovisões dos povos tradicionais das Américas, de "dentro e fora do mundo andino e amazônico", Acosta discorre sobre a noção do buen vivir como proposta de reflexão acerca de outras formas de organização social e práticas políticas. Segundo ele, "o bem viver é, essencialmente, um processo proveniente da matriz comunitária de povos que vivem em harmonia com a Natureza". Assim como os povos oriundos das diferentes matrizes africanas, as sociedades tradicionais do continente americano são detentoras de histórias e conhecimentos ancestrais que resultam em formas de conceber o mundo e a relação entre os seres. Mesmo marginalizados, tais grupos resistiram ao colonialismo e à modernidade, revigorando seus saberes e suas tecnologias. Logo, o autor defende que tais cosmovisões precisam ser acessadas e difundidas já que contribuem com os grandes debates globais em prol de um mundo sensível e democrático, calcado nos Direitos Humanos e da Natureza. Cf. ACOSTA, A. O bem viver: uma oportunidade de imaginar outros mundos. São Paulo: Autonomia Literária, Elefante, 2016, p. 24.

${ }^{29}$ SANTOS, A. S. A. A Dimensão Africana da Morte resgatada nas Irmandades Negras, Candomblé e Culto de Babá Egun. 244 f. Dissertação (Mestrado em Ciências Sociais) - Pontifícia Universidade Católica de São Paulo, Departamento de História, São Paulo, 1996, p. 105.

${ }^{30} \mathrm{O}$ termo refere-se às proposições de Benjamin. A ideia aqui é apreender os sentidos e os desdobramentos das irmandades brasileiras a partir de concepções que caminham na contramão dos discursos hegemônicos vigentes, para além das ideias consolidadas pelos grupos dominantes, na tentativa de contribuir para que outras epistemes possam emergir e confluir em um entendimento mais amplo destas instituições e práticas ancestrais. Sobre o termo leitura à contrapelo, ver: LOWY, M. Walter Benjamin: aviso de incêndio, uma leitura das teses "Sobre o conceito de história". São Paulo: Boitempo, 2005.
}

${ }^{31}$ SANTOS, op. cit., p. 61. 
ocidental $^{32 \prime \prime}$.

Cabe aqui fazer uma breve retrospectiva e pontuar que os acordos tácitos e negociações complexas dos povos africanos que vieram para a América não se deram de imediato. Suas práticas se mantiveram embora os significados dos ritos se tenham transformado à medida em que tentavam lidar com a nova condição, situação e ambiente. Dessa forma, as(os) africanas(os) perpetuaram, mesmo no cristianismo, suas concepções de mundo ${ }^{33}$ e segundo Sweet:

a aceitação do catolicismo entre os africanos foi lenta e desigual, e mesmo quando parecem registrar-se manifestações da fé cristã, continuam a poder ser encontrados elementos do passado religioso africano em coexistência com as práticas cristãs ${ }^{34}$.

Portanto, as narrativas de Dona Lucinda revelam aspectos que se relacionam às mundivivências africanas reelaboradas e recriadas no território brasileiro, ao serem transmitidas de geração em geração enquanto práticas ancestrais.

As digressões e constantes repetições que marcam um ritmo para as narrativas de Dona Lucinda podem ser interpretadas, nas palavras de Glissant, como a "tentativa de aproximar uma realidade tantas vezes ocultada" e que, portanto, "não se ordena de repente em torno de uma série de claridades. Nós reclamamos o direito à opacidade ${ }^{35 \prime \prime}$.

Mais adiante, a colaboradora partilha:

Minha mãe nasceu em Bananal [São Paulo, Vale do Paraíba], mas foi criada no Rio de Janeiro, e bem mocinha ela veio pra cá e casou. Ela se chama Luzia Barbosa de Oliveira e meu pai, Pedro de Oliveira. E quando é mês de outubro tem a Festa de São Benedito lá no Rio [RJ], eu vou pra lá, mas eu fico na casa dos meus parentes lá em São João do Meriti, em Caxias, sabe aonde é? É sempre no mês de outubro a festa lá e aqui é na segunda semana de janeiro.

Minha mãe fazia muita excursão sabe, ela gostava muito de reunir as pessoas, ela fazia pra Tambaú, pra Aparecida do Norte, Pirapora, aí enchia o ônibus e depois que ela faleceu eu continuei com Aparecida do Norte. E todos os anos a gente vai ... Eu não parei. Olha, é tanta gente que quer ir, que já tá lotado o ônibus [ao se referir a viagem deste ano, em abril de 2018], tem gente até na lista de espera, é bastante gente. Somos devotas de Nossa Senhora e de São Benedito.

\footnotetext{
32 Ibid., p. 17.

${ }^{33}$ SAVIETO, op. cit., p. 46.

${ }^{34}$ SWEET, J. H. Recriar África: cultura, parentesco e religião no mundo afro-português (1441-1770). Lisboa: Edições 70,2007 , p. 225.

${ }^{35}$ GLISSANT, É. Le discours antillais. Paris: Éditions du Seuil, 1981, p. 11.
} 
Aí ela faleceu e eu continuei, esse almoço grande que eu faço, era ela que fazia. Quando ela faleceu eu já tinha a minha filha, que também chama Luzia em homenagem à minha mãe. Eu tenho três filhos, o do meio chama João Carlos, mas o apelido dele é Nenê, tenho a Luzia e a Julia, que já faleceu.

Aqui, é oportuno observar que o comprometimento firmado por Dona Lucinda junto à comunidade da Casa Verde e do Parque Peruche também se estende para outras comunidades, formando uma rede de interações, um manancial de solidariedade por onde se reagrupam diversas Irmandades. Uma ética comunitária na qual família e irmandade se confundem parece prevalecer, a fim de contribuir para a preservação dessa tradição viva de devoção à São Benedito.

A colaboradora preocupa-se em participar todos os anos da festa de São Benedito no Rio de Janeiro, reunindo-se à família materna e zelando pelos laços de parentesco que atravessam fronteiras, marcando lugares de memórias ancestrais afetivas. As narrativas de Dona Lucinda atuam de forma a orientar suas/seus interlocutoras(es) à reconstruir, pelas veredas de suas lembranças, caminhos percorridos por muitas famílias negras, formando elos que resistiram ao sistema escravista, subverteram a ordem imposta no contexto do pós-abolição e sobreviveram, renovando suas tradições por meio de suas festas e de suas religiosidades.

Para além do almoço em comemoração à festa da Irmandade de São Benedito, Dona Lucinda também relata que sua mãe organizava romarias e viagens para cidades de grande importância religiosa para a comunidade cristã, como Aparecida do Norte, Pirapora do Bom Jesus e Tambaú. E na tentativa de manter essa tradição iniciada por sua mãe, Lucinda ainda organiza a viagem para Aparecida do Norte, agregando muitas(os) devotas(os) da zona norte de São Paulo. Aqui, o protagonismo da colaboradora é apresentado mais uma vez a partir da persistência em prosseguir com as práticas de fé e a ética comunitária de sua mãe, ancestral viva em suas memórias, reverenciada por toda a comunidade.

Aliás, ao se tratar das memórias de Luzia Barbosa de Oliveira, Dona Lucinda sinaliza outro elemento que conflui para o que se pode atribuir como marca da presença de ancestralidades negras em comunidades afrodiaspóricas. A colaboradora nomeou sua filha Luzia em homenagem à mãe e ela mesma recebeu seu nome em homenagem à bisavó, também chamada Lucinda. São linhagens uterinas que se mantêm vivas, resguardando valores civilizatórios por meio das práticas ancestrais herdadas e reelaboradas. Tais concepções apontam para cosmologias africanas que detêm como base de suas práticas o culto às(aos) antepassadas(os). 
A esse respeito, Altuna asserta que em comunidades bantu "a união vital do nome com a essência da pessoa entra no campo da magia, está exposta à interação vital ${ }^{36 ”}$. Assim:

Com frequência dão a/ao menina (o) o nome de um(a) antepassada(o), sobretudo se a sua concepção foi atribuída a seu favor, se lhe encontram alguma parecença, ou se desejam manifestar a sua presença e estima. Consegue-se assim uma comunhão vital transformadora e vivificante ${ }^{37}$.

Acerca de suas antigas e seus saberes afro-ancestrais, Lucinda recorda e revela:

Minha mãe tinha o dom de benzer, mas ela benzia só criança. Aí enchia de gente, tudo, vinha a criançada toda que ela benzia, mas eu não peguei o dom dela não. $O$ pessoal até brigava. O pessoal que não entendia de benzimento, né. A gente tinha uma vizinha aí que brigava, xingava minha mãe até de feiticeira sabe, ela sabia que as crianças vinham, saravam e ficavam boa, e minha mãe falava, eu não sou feiticeira, eu faço bem pras crianças, e eu lembro que ela benzia até com cinzas, que tinha fogão à carvão. E ela ia me ensinar, mas não deu tempo. Eu sei que ela pegava as cinzas no prato e com a faca ela punha a cinza no prato, ai minha mãe cruzava assim, e ela benzia nas cinzas de carvão com uma faca. Ela aprendeu com a minha bisavó que também era benzedeira e também se chamava Lucinda. Meu nome é em homenagem a minha bisa. Minha avó chamava Julieta e minha bisa Lucinda, elas eram do interior do Rio, de Barra Mansa [Vale do Paraíba, RJ]... Ela contava da minha bisavó que foi escrava, ela trabalhava de cozinheira e o patrão gostava dela, ela cozinhava... Ela queria me ensinar mais, mas eu não me interessava muito na época, depois ela faleceu. E minha mãe, eu lembro bem, salvou muita criança que vinha quase morrendo e ela curava. Eu sei que ela rezava baixinho e cada vez que ela ia benzer a mãe da criança tinha que repetir o nome da doença. Ela virava a criança de costas e rezava, mas eu acabei não aprendendo.

De acordo com a narrativa de Dona Lucinda, é possível constatar que suas/seus antepassadas(os) maternas(os) habitaram algumas cidades do Vale do Paraíba como, por exemplo, Barra Mansa (RJ) e Bananal (SP). Tal região é marcada historicamente por forte presença centro africana e, portanto, elementos da cultura bantu se expressam e são traduzidos por negras(os) que viveram nesse território e transmitiram seus conhecimentos e tecnologias às/aos suas/seus descendentes. Estas(es), por sua vez, promoveram migrações, vieram para o município de São Paulo, e compõem aqui, mais precisamente, parte do segmento populacional da região da zona norte, como os subdistritos do Parque Peruche e da Casa Verde Média.

\footnotetext{
${ }^{36}$ ALTUNA, op. cit., p. 269.

${ }^{37}$ Ibid., p. 269.
} 
Tendo em vista tais considerações, é de ressaltar que, de acordo com Savieto:

quando falamos em linguagens da África Central no Brasil, necessitamos de uma abordagem abrangente. Esta linguagem ou cultura é múltipla em sua forma: é oral, corporal, sonora, rítmica, responsorial, além de ser presencial e comunitária, e, como tal, é viva, dinâmica e implica em transgressões e traduções ${ }^{38}$.

Portanto, quando a colaboradora Lucinda reconstrói as memórias de sua mãe, de sua avó e de sua bisavó, elementos da matriz bantu podem ser sinalizados, já que se constituem em permanências históricas que foram herdadas e reatualizadas.

É interessante perceber que mesmo sendo muito católica, a mãe de Lucinda preservara um saber afro-ancestral de sua avó, mulher negra, cozinheira e benzedeira que fora escravizada no século XIX. Enquanto benzedeira, Dona Luzia performou e atualizou saberes ancorados em rastros de memória de povos africanos. Aqui, a saúde é entendida a partir de uma dimensão cósmica e sobretudo comunitária sobre a qual a espiritualidade é partícipe na manutenção da vida dos seres, e nesse caso, das crianças, símbolos concretos da continuidade geracional.

Ao executar movimentos cruzados com uma faca sobre as cinzas e ao proferir o nome da doença a ser combatida, ${ }^{39}$ a mãe de Lucinda parece reatualizar saberes civilizatórios do Kongo, por exemplo. Tais códigos podem estar associados à força presente no cosmograma yowa que, segundo Thompson, significa:

a visão igualmente poderosa do movimento circular das almas humanas sobre a circunferência de suas linhas cruzadas [...] A virada na trilha, isto é, a encruzilhada, permanece um conceito indelével do mundo atlântico Kongo como o ponto de cruzamento ou de intenção entre os ancestrais e os vivos ${ }^{40}$.

Ao dominar tais técnicas, a benzedeira pôde combinar palavras e imagens promovendo a cura das crianças e orientando as famílias quanto à necessidade de manutenção da saúde. A doença então é apreendida a partir de sua dimensão social, já que implica um desequilíbrio por onde muitas forças se combinam ou se chocam. De acordo com tal tradição, pontos cruzados

\footnotetext{
${ }^{38}$ SAVIETO, op. cit., p. 52.

${ }^{39}$ A esse respeito, é possível também sinalizar algumas correspondências com as práticas de encantamento (ofós) entre as (os) iorubas. De acordo com Ribeiro e Sàlámì, o termo pode ser entendido "como a palavra falada possuidora de força mágica ou capaz de produzir efeitos mágicos quando recitada ou cantada". Tais ofós são muito utilizados na prática médica e, nesse sentido, "o conhecimento dos nomes da morte ou da doença" contribuem para o processo de cura e possibilitam a longevidade. Exemplo: “...(nome), mo orúko yin-ín / Kí e má bá mi wí!” / Trad.: "...(nome), sei seu nome. Não me perturbe!”. Cf. RIBEIRO; SÀLÁMì, op. cit., p. 46-48.

${ }^{40}$ THOMPSON, op. cit., p. 112.
} 
permitem invocar a força divina e a força das(os) ancestrais, na tentativa de promover a cura de uma enfermidade por meio dessa mediação.

Assim, as narrativas de Dona Lucinda possibilitam reflexões acerca das cosmovisões das matrizes bantu. E no que se refere aos saberes Kongo, tal microexperiência histórica, reconstruída pelos trabalhos de memória da colaboradora, parece contribuir para os estudos que visam o reconhecimento de ciências e valores civilizacionais no mundo negro atlântico. Nesse sentido, como assinala Thompson, ao tratar de uma conjuntura mais ampla:

Igualmente disseminados e espalhados pelo mundo negro atlântico estão os sinais, as marcas e as percepções do grandioso povo Kongo do Zaire, de Angola, de Cabinda e do Congo-Brazaville. Existe uma conexão clara entre as marcas ou sinais cosmográficos do renascimento espiritual na religião clássica dos Bakongo e os sinais de iniciação, desenhados a giz, similarmente delineados pelos negros de Cuba, do Haiti, da Ilha St. Vincent, dos Estados Unidos e do Brasil, onde aportaram numerosos escravos Kongo ${ }^{41}$.

Consoante à tal perspectiva, é legítimo afirmar que as civilizações negro-africanas foram capazes, nas palavras de Leite:

de absorver novas propostas, oriundas de vários horizontes, e reproduzi-las com a autonomia garantida pela sua materialidade própria e criando novas sínteses. Esta capacidade sintética, que mantem a singularidade na pluralidade, permite considerar que essas civilizações não se encontram fechadas e voltadas para $\mathrm{si}^{42}$.

Ou seja, enquanto culturas compósitas ${ }^{43}$, e longe de cristalizar tais práticas ou estabelecer uma dualidade diante as práticas euro-cristãs, os padrões civilizacionais negro-africanos puderam se materializar de forma a compor uma gama de repertórios culturais que agregaram, adaptaram e serviram-se de muitas das matrizes às quais tiveram contato. Ao particularizar o catolicismo, por exemplo, Sweet constata que africanas(os) e suas/seus descendentes adotaram uma dupla pertença com a finalidade de complementar suas cosmovisões, assim:

Essa convivência se tornou possível graças à capacidade dessas populações de relacionar a nova religião, a religião do colonizador, as suas formas de compreender o mundo. O catolicismo muitas vezes serviu como mais um

\footnotetext{
${ }^{41}$ THOMPSON, op. cit., p. 18.

${ }^{42}$ LEITE, F. Valores civilizatórios em sociedades negro-africanas. África: Revista do Centro de Estudos Africanos, USP, São Paulo, v. 1, p. 103-118, 1995/1996, p. 116-117.

${ }^{43}$ GLISSANT, É. Introdução a uma poética da diversidade. Juiz de Fora: Editora UFJF, 2005.
} 
instrumento de solução dos problemas temporais, seus ritos e símbolos foram transformados e integrados às visões religiosas e sociais de africanos e seus descendentes pelo mundo ${ }^{44}$.

Portanto, as narrativas orais de Dona Lucinda apresentam elementos que permitem reconhecer na Irmandade de São Benedito todo um conjunto de tradições compartilhadas, por onde se entrecruzaram cosmovisões e por onde se estabeleceram negociações. A irmandade fundamenta-se no entre lugar de povos africanos e suas/seus descendentes, reinventando valores e códigos meio aos traumas $^{45}$ vividos diante do tráfico, do rompimento dos laços de pertencimento, dos laços de parentesco e, por isso, reconstruindo formas fractais e transgressoras de (re)existência vinculadas à incessante busca em resgatar a família-comunidade e as linhagens.

A colaboradora parece reconhecer, ao acessar as lembranças de sua mãe, a necessidade de perenizar a memória de suas antigas, detentoras de saberes ancestrais herdados. Dona Lucinda manifesta um certo arrependimento por não ter dado no passado a devida atenção à sua mãe no momento em que esta poderia ter Ihe ensinado as técnicas da prática do benzimento. No entanto, ao engajar-se no trabalho junto à Irmandade, ao lutar para que todos os anos seja organizado o almoço na rua Galileia e ao nutrir a rede de sociabilidades que conecta as diferentes comunidades negras, Dona Lucinda perpetua não só a memória de sua mãe como também de suas/seus antepassadas(os), resguardando os valores afrodiaspóricos que fundamentam e dão sentido a tais práticas ancestrais.

Ao tratar da vizinha que não entendia de benzimento, chamando a Dona Luzia de "feiticeira", a colaboradora reatualiza uma situação sobre a qual é possível notar como as práticas ancestrais afro-brasileiras eram e ainda são apreendidas por uma parcela da população. O ofício de benzer, que compreende um vasto repertório de técnicas baseadas no segredo e na manipulação de energias vitais para a obtenção da cura ou para o encaminhamento de um tratamento, foi interpretado neste contexto de forma pejorativa, como um problema relacionado ao mal.

\footnotetext{
${ }^{44}$ SWEET, op. cit., p. 244.

${ }^{45}$ Cabe ressaltar que a ideia de trauma nesta pesquisa é entendida a partir de sua perspectiva histórica e intergeracional. A esse respeito, Gomes asserta, ao tratar da questão no seio de comunidades afrodiaspóricas: "um trauma histórico pode provocar modificações profundas no funcionamento do grupo e de seus indivíduos, com a consequente retraumatização dos seus membros. A violência sofrida pelos membros de um grupo social pode ser retransmitida, de maneira simbólica, aos indivíduos das gerações subsequentes, que atualizam não só o núcleo do trauma, como podem produzir a sintomatologia correspondente". Cf. GOMES, A. M. de A. "Melhor que o Mel, só o Céu": trauma intergeracional, complexo cultural e resiliência na diáspora africana (um estudo de caso do Quilombo do Mel da Pedreira, em Macapá, AP). 277f. Tese (Doutorado em Psicologia Clínica) - Pontifícia Universidade Católica de São Paulo, São Paulo, 2017, p. 26.
} 
Aqui, uma visão dicotômica e eurocentrada acerca da realidade parece dar sentido a tais considerações. A vizinha parece não captar a complexidade de um saber milenar que traduz cosmovisões distintas ao paradigma ocidental e que escapam aos sentidos cartesianos. Ao reproduzir concepções e valores da "modernidade", a antagonista da narrativa de Dona Lucinda parece reconstruir a base de um pensamento hegemônico que sempre buscou deslegitimar e minar os conhecimentos e as práticas mágico-ancestrais ou mágico-religiosas dos povos negros, descendentes da diáspora africana. Em termos históricos, de acordo com Savieto, tal ideia se aproxima de um pensamento novecentista, segundo o qual:

Por feitiçaria, os europeus entendiam uma atuação permeada de intenções maléficas e mesmo como intervenções demoníacas. Por outro lado, em muitas línguas africanas não havia palavras distintas para designar rituais bons ou maus. "Feitiçaria" seria, genericamente, sinônimo de "poderes religiosos" para manter o equilíbrio entre vivos e mortos, como entre forças e energias da natureza. Se não há palavras distintas para designar esta dualidade no ritual é porque o africano não về estes poderes de forma bipartida. Esta concepção é eminentemente cristã $^{46}$.

Portanto, a atitude intolerante da vizinha, projetada contra a mãe de Lucinda, apoia-se em lógicas de poder que consolidaram os racismos religiosos ${ }^{47}$, ainda presentes em nossa sociedade.

Enquanto mulher negra, benzedeira e fundadora da Irmandade de São Benedito, Dona Luzia transgredira uma realidade social, tendo em vista seu protagonismo e amplo conhecimento. Por isso, acessar narrativas que contemplem tais saberes é poder tecer novos pontos de vista por onde até mesmo o catolicismo é traduzido e concebido sob a ótica de uma benzedeira na metrópole paulistana. Tais memórias suscitam possibilidades que se desnudam em lembranças de um universo de subjetividades negras aqui compartilhadas.

Entre fotos e demais documentos, a sala de Dona Lucinda transmuta-se e no movimento descontínuo de suas reminiscências, o tempo presente se refaz. Ao fazer um convite para conhecer o santo da casa, a colaboradora compartilha:

Minha mãe era costureira e ela que fazia as roupas da irmandade de São Benedito

\footnotetext{
${ }^{46}$ SAVIETO, op. cit., p. 94-95.

${ }^{47} \mathrm{O}$ termo aqui empregado é entendido como violência que merece ser denunciada e combatida. Nesse sentido, Fernandes completa que tais práticas de intolerância: "são ataques físicos e verbais [...] Evidenciam-se como racismo religioso, pois acreditamos que as agressões são feitas em sua totalidade por constituírem-se como uma negação às visões de mundo africanas, assim sendo uma das facetas do racismo brasileiro". Cf. FERNANDES, A. P. da S. Candomblé de São Paulo: fundamentos e tensões de uma comunidade terreiro na metrópole.129 f. Dissertação (Mestrado em História) - Pontifícia Universidade Católica de São Paulo, São Paulo, 2017, p. 60.
} 
[...] São Benedito é um santo cozinheiro, vamos lá na cozinha que eu vou mostrar ele. [Em direção à cozinha]. Então, todo dia eu faço o café e ponho lá, e do lado de cá tem café moído. Ele é protetor dos cafezal, ele lidava com café. O primeiro café vai pra São Benedito e o café moído também fica lá. No dia da festa, a primeira coisa que a gente serve é o café, eu sirvo café completo. E minha mãe fazia a mesma coisa, da mesma forma. E aqui aonde é a cozinha hoje, antes era a capela, todo esse corredor era a capela da minha mãe. Aqui eu dava catecismo pras crianças também.

Nessa passagem Dona Lucinda manifesta a sua devoção à São Benedito. E mesmo se tratando de uma prática cristã, as linguagens simbólicas presentes na estátua e a relação de culto ao santo se dão a partir de horizontes culturais oriundos das matrizes africanas. São Benedito, enquanto santo católico, manifesta-se dentro e fora da Irmandade como símbolo da negritude, da comunidade negra, associado à trajetória e ao passado de muitas(os) afrodescendentes. A devoção a ele reatualiza o culto às(os) ancestrais e marca a permanência de cosmovisões africanas nas formas de se praticar o catolicismo. Trata-se, portanto, de uma tradução de códigos culturais de uma sociedade por outra garantida pelo compromisso com uma tradição que se reinventa permanentemente.

Oferecer-lhe o primeiro café do dia, saudá-lo cotidianamente, reconhecer o lugar do santo no interior da família, configura-se em uma prática que muito se assemelha a alguns princípios inerentes à cultura bantu. Altuna considera que os bantu estendem "a sua personalidade, domínio e força vital até aos objetos que lhe pertencem ${ }^{48 \prime \prime}$, a partir de uma lógica por onde tudo e todas(os) são partícipes de um dinamismo vital, os seres vivos, as(os) mortas(os) e os objetos por elas(es) adquiridos ou apropriados. Nessa perspectiva, o santo da casa, ao ser nutrido e considerado pela família, atua de forma a assegurar parte do dinamismo vital necessário à sobrevivência de todas(os).

Mais adiante, ao explicar o sentido de cada objeto e elemento que compõem o altar de São Benedito e de Nossa Senhora Aparecida, a colaboradora relata:

Todo ano a minha filha troca as flores, a capa dos santos. Tem Cosme e Damião também, quando tem festa de Cosme, a gente faz bolo também e a gente deixa um pedaço de bolo pro santo.

Aqui, o culto à Cosme e Damião também integra o conjunto de práticas vivenciadas

${ }^{48}$ ALTUNA, op. cit., p. 532.

Odeere: Revista do Programa de Pós-Graduação em Relações Étnicas e Contemporaneidade - UESB. ISSN: 2525-4715 - Ano 2018, Volume 3, número 6, Julho - Dezembro de 2018. 
diariamente por Dona Lucinda e sua família. É interessante perceber que algumas/alguns santas(os) são sobretudo cultuadas(os) pelas comunidades negras, como Nossa Senhora do Rosário, São Benedito, São Sebastião, São Jorge, Santa Ifigênia, e São Cosme e Damião. Tais santas(os) foram crioulizadas(os) ${ }^{49}$ e agregadas(os) às representações do vasto universo africano.

Um exemplo dessa interação é a difusão do culto à Cosme e Damião, figuras gêmeas que são veneradas em muitas culturas africanas. Entre as(os) iorubas ${ }^{50}$ ou entre muitos povos da matriz bantu, as (os) gêmeas(os) relacionam-se à força vital que constitui a dualidade. Esta é entendida enquanto polo de complementaridade sobre o qual se manifestam energias plurais capazes de transformar a realidade, revertendo a ordem das coisas e abrindo os caminhos em direção à prosperidade. O culto à Ìbéjì, divindade relacionada a essa força vital para as(os) iorubas, prolonga-se na percepção e na relação que as famílias estabelecem com as crianças nascidas gêmeas. Estas, são cultuadas e reverenciadas porque carregam a energia da própria divindade. 0 mesmo se aplica também em muitas culturas bantu, onde a chegada de gêmeas(os) na família é sinal de celebração e agradecimento ao universo. As(os) nascidas(os) depois de gêmeas(os), nomeadas(os) de Fuxi em língua quimbundo, são encarregadas(os) de render culto às(aos) irmãs(ãos), para assegurar a prosperidade da própria família. Esta, por sua vez, não deve contrariá-las(os), caso contrário poderá atrair infortúnios para a comunidade.

Tais particularidades compõem uma gama de sentidos e significados que fazem do culto à Cosme e Damião algo comum entre populações afrodiaspóricas. No entre-lugar das fronteiras culturais, tais práticas se entrecruzaram e traduzem mesmo em roupagem cristã, cosmovisões africanas reinventadas nos territórios da diáspora.

Quando relata de forma precisa que "o primeiro café vai pra São Benedito e [..] No dia da festa, a primeira coisa que a gente serve é o café", Dona Lucinda reatualiza por meio da festa um ritual cotidiano que se estende para o acolhimento de toda a comunidade. Esse momento da narrativa parece dimensionar o próprio espaço da cozinha. A antiga capela da residência é adaptada e transformada em cozinha para a família. Porém, no dia da festa essa cozinha é estendida para a sala e para o quintal da frente, já que será preciso preparar um café da manhã e um grande almoço para toda a comunidade. A rua Galileia também se transforma em grande salão

\footnotetext{
${ }^{49}$ Glissant, ao engendrar o conceito de crioulização apresentado enquanto relação constituída por ineditismos que produzem combinações múltiplas e provisórias, portanto imprevisíveis, opõe-se à ideia eurocêntrica da mestiçagem. Dessa forma, o termo aqui refere-se às diversas possibilidades manifestadas pelos repertórios culturais das comunidades afro-brasileiras, que se configuram em identidades rizomórficas, ou seja, "não mais como raiz única, mas indo ao encontro de outras raízes". Cf. GLISSANT, op. cit., p. 27.

${ }^{50} \mathrm{O}$ termo refere-se aos povos africanos de língua e cultura do mesmo nome, oriundos da região que reúne os países Nigéria, Togo e Benin. Uma das bases da cosmovisão ioruba é o culto aos orixás, forças vitais da natureza presentes em todos os seres dos reinos animal, vegetal e mineral.
} 
por onde vão se reunir todas(os) que desejam desfrutar dessa grande celebração de partilha em homenagem ao santo cozinheiro.

Logo, a festa transcende a lógica da casa e do bairro, transmutando parte da cidade. Assim fundamenta-se a magia da festa, um ritual que se reproduz durante anos tendo como protagonistas as mulheres negras. Ao tratar das múltiplas linguagens (corporal, performática e musical) que englobam o sentido da festa, Savieto completa:

$\mathrm{Na}$ festa, os participantes criam atuações e narrativas, que alimentam, posteriormente, memórias. A festa é protagonizada e, depois, revisitada, através de memórias e narrativas, múltiplas vezes. Nas festas, tanto nos momentos de protagonismos como nos de rememoração, comunidades são forjadas, o grupo passa a existir ou torna-se mais coeso ${ }^{51}$.

Ao combinar cotidiano, festa e instituição, as irmandades negras e, em particular, a Irmandade da Casa Verde, constitui-se em um importante território político e simbólico para a comunidade afrodescendente. Tal territorialidade só é construída tendo em vista os inúmeros confrontos, resistências e negociações para a luta em prol da dignidade negra na metrópole.

No fluir de suas narrativas, a própria colaboradora relata inúmeras vezes uma fase difícil em que ela precisou lutar para tornar oficial a festa de São Benedito nas comunidades da Casa Verde e Parque Peruche, diante dos impedimentos e críticas empreendidos por membros, mais precisamente homens, associados à Paróquia, e que julgavam a iniciativa de Dona Lucinda incompatível com os eventos ditos oficiais da instituição. De fato, o almoço organizado por Dona Luzia e por Dona Lucinda, escapa à lógica atávica da instituição religiosa e, portanto, agrega muito mais gente por acolher a comunidade de uma forma particular. Dessa forma, mulheres negras, ambas as protagonistas, vêm transgredindo formas dominantes do poder, consolidando na urbe paulistana suas identidades afirmadas.

Relembrar sua trajetória e reconhecer os percalços para a perpetuação das memórias das(os) suas/seus antigas(os) é um trabalho cotidiano que dá sentido e vitalidade à protagonista negra, Dona Lucinda. Quando menciona, "e minha mãe fazia a mesma coisa, da mesma forma", a colaboradora parece se orgulhar de poder continuar uma iniciativa semeada e cultivada, dentre outras(os), por sua mãe.

No que tange às fotografias, é possível constatar o quanto tais portais de memórias possibilitaram o primoroso trabalho de costura das lembranças, por onde um passado é recriado, revisto e reatualizado. Tais fontes de recordação e de emoção representam fragmentos

\footnotetext{
${ }^{51}$ Savieto, op. cit., p. 64.
} 
interrompidos da vida, e segundo Kossoy:

Estamos envolvidos afetivamente com os conteúdos dessas imagens; elas nos dizem respeito e nos mostram como éramos, como eram nossos familiares e amigos. Essas imagens nos levam ao passado numa fração de segundos; nossa imaginação reconstrói a trama dos acontecimentos dos quais fomos personagens em sucessivas épocas e lugares ${ }^{52}$.

Cabe aqui também compartilhar das lembranças emergidas e reconstruídas por Dona Lucinda quando esta adentrou no universo proposto por uma fotografia em particular.

Figura 1. Momento de celebração que antecede o almoço da festa da Irmandade de São Benedito da Casa Verde em São Paulo/SP. Início do mês de janeiro (s/data)

Fonte: Acervo pessoal de Lucinda de Oliveira Marcelino.

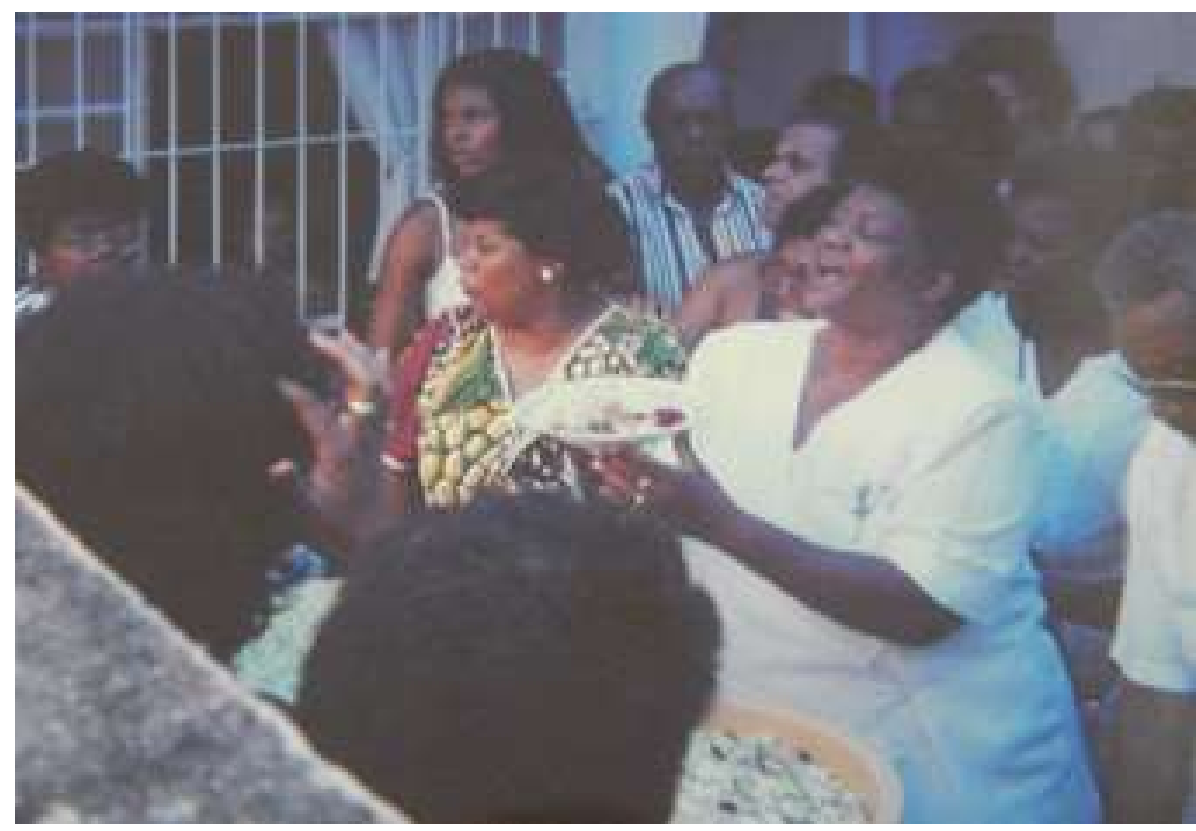

As imagens desta fotografia (Figura 1) evocaram a seguinte narrativa:

Essa foto era quando o almoço era aqui dentro de casa, aí punha a mesa de comida e cada um pegava o seu prato e ia sentar lá na rua. Antes de servir a comida, a lolanda tá rezando e agradecendo à São Benedito pela comida que foi feita e que a gente vai servir. Ela tá abençoando a comida. Aí nós estamos cantando o hino de São Benedito, oferecendo a São Benedito. Esse prato é pra ele, pra ele abençoar a comida! E todo mundo comia, bebia e tem a sobremesa também que é o bolo.

É interessante perceber que aqui o momento de celebração atinge seu ápice quando

${ }^{52}$ KOSSOY, B. Fotografia \& História. São Paulo: Ateliê Editorial, 2001, p. 100. 
todas(os) são convidadas(os) a partilhar do grande banquete oferecido ao santo patrono e à comunidade. A comida é sacralizada, já que fora preparada, oferecida e compartilhada às(aos) vivas(os), às(aos) antepassadas(os) e ao santo. Tais dimensões da oferenda materializam o sentimento de gratidão e respeito a partir de um ritual que só faz sentido quando estendido e vivenciado por toda a comunidade.

A essa prática ancestral, podem comungar permanências de cosmovisões africanas como, por exemplo, às de tradição ioruba. Para tais grupos, (as)os deusas(es) e as(os) ancestrais comem pela boca(das) dos seres, portanto é comum em suas práticas os grandes banquetes e as oferendas. Além disso, a força vital (axé) presente nos alimentos e na ação humana daquelas(es) que cozinham confluem para nutrir o corpo-alma/espírito, apreendidos aqui a partir de uma dimensão distinta à visão ocidental, já que tudo está interligado e, portanto, configurado em uma grande rede de participação integrada. Nessa perspectiva, a manutenção da vida e da morte se dá por meio da comida que dinamiza o fluxo da existência dos indivíduos e, sobretudo, da comunidade.

Consoante à tal perspectiva e de acordo com a cosmologia das diversas comunidades tradicionais de terreiro, é possível afirmar que:

Plantas, animais e homens são igualmente seres encantados. Com uma diferença apenas: por detrás das suas múltiplas máscaras, sejam elas minerais, vegetais, animais ou humanas, espreita a matéria primordial e divina à qual foram subtraídos ${ }^{53}$.

Nesse sentido, por onde aquém e além não se encontram definitivamente separados, a cinestesia e a culinária presentes nas práticas ancestrais afrodiaspóricas conjugam-se de forma a perpetuar a ocasião ritual. Esse momento só pode ser legitimado pela evocação do poder da força vital incorporado à palavra, diante à reza, aos agradecimentos e aos cânticos enunciados. A esse respeito, Lucinda e sua filha cantam e partilham do hino-oração em homenagem à São Benedito:

\author{
Levantemos nossa voz \\ A São Benedito que é nosso Protetor \\ Que rogando a Deus por nós \\ Dê graças também ao Senhor \\ Ó meu São Benedito \\ Confiamos em seu poder \\ Bradar as almas que é nosso grito
}

\footnotetext{
${ }^{53}$ VOGEL, A.; MELlo, M. A. da S.; BARROS, J. F. P. de. A galinha d'angola: iniciação e identidade na cultura afrobrasileira. 3a. ed. Rio de Janeiro: Pallas, 2007, p. 26.
} 
O tentador queremos vencer

Levantemos nossa voz

Reconhecida no grande amor de Deus

Tirando do nada a nós

Para sermos verdadeiros filhos teus

Nosso Santo Protetor

Tenha-nos sempre amparados em vossa alma

Humilhada é a nossa cor

Queremos exaltar a nossa alma

Venceremos a peleja

Com São Benedito cantaremos Hosana

Sempre firme a fé na Igreja

Católica Apostólica Romana. ${ }^{54}$

Mesmo ao marcar a devoção ao santo cozinheiro e o comprometimento ao cristianismo católico, a letra do hino da Irmandade também revela liturgicamente por meio das palavras evocadas a luta pela afirmação da humanidade e da dignidade da comunidade negra, meio aos percalços que podem englobar aqui a violência e os traumas vividos e herdados por todas(os). A força presente na ressonância desse hino-oração permite às(aos) suas/seus locutoras(es) expressar, por meio do corpo, as emoções memorizadas, traduzindo repertórios culturais permeados por inventividade e resistência.

Historicamente, os elementos presentes em tais culturas de resistência puderam forjar identidades afirmadas entre as(os) afrodescendentes nas Américas, contribuindo para a permanência e perpetuação de suas práticas reelaboradas na contemporaneidade, dentre as quais, as irmandades negras. Assim, as tradições negras se reinventaram a partir de interações fronteiriças ou situações "entre-lugares", meio às dificuldades e às adversidades impostas pela escravidão, pelo capitalismo, pela modernidade ocidental e pelo racismo institucional. Essa situação corroborou para que as comunidades negras atuassem na dialética do poder, tendo em vista o espírito brecheiro ${ }^{55}$ que caracteriza a produção cultural das(os) negras da diáspora. Nessa linha de pensamento e nas palavras de Bhabha:

O "direito" de se expressar a partir da periferia do poder e do privilégio autorizados não depende da persistência da tradição; ele é alimentado pelo poder da tradição de se reinscrever através de condições de contingência e

\footnotetext{
${ }^{54}$ Hino-oração da Irmandade de São Benedito da Casa Verde (SP).

${ }^{55} \mathrm{O}$ termo aqui refere-se à noção de filosofias brecheiras. Tal conceito foi cunhado na tentativa de definir as formas de pensamento que escaparam aos pilares dos sistemas hegemônicos, produzindo o que Gilroy, ao tratar do Atlântico Negro, definira como caminhos transversais, estruturas fractais de infinitas possibilidades. Cf. GILROY, P. op. cit., p. 33- 100 .
} 
contraditoriedade que presidem sobre as vidas dos que estão "na minoria" ${ }^{56}$.

Logo, a Irmandade de São Benedito da Casa Verde, desde a sua fundação em 1941, em consonância às iniciativas de suas/seus protagonistas negras(os), congrega uma gama de elementos, sentimentos e memórias que se configuram em traduções de Áfricas na zona norte de São Paulo (SP).

E mais adiante, no passar do tempo linear, no anoitecer das horas, Dona Lucinda compartilha de uma reflexão existencial:

Acho que é isso que não deixa a gente tropicando, não deixa a gente caída, a gente que tem idade tem que ter uma atividade, né. Se a gente ficar só em casa, em casa, em casa né, é aonde você se acaba e fica doente. Enquanto eu puder tó andando, saindo e me divertindo né, aí tô eu. O dia que Deus falar chega, o dia que me chamar, eu já me diverti bastante, já sai bastante.

Tais palavras fecundas comungam com a noção do bem viver estudada por Acosta. Enquanto "parte de uma grande busca de alternativas de vida, forjadas no calor das lutas da humanidade pela emancipação e pela vida ${ }^{57 \prime \prime}$, essa forma de (re)existência assumida por Dona Lucinda revela cosmovivências que se opõem ao emudecimento, ao amordaçamento e às demais violências pelas quais negras(os) são confrontadas(os) no Brasil. As reflexões da colaboradora produzem subsídios para o fortalecimento de epistemologias do sul $^{58}$ e atuam na contramão do sistema neoliberal ${ }^{59}$ pelos fluxos descoincidentes da ancestralidade, ao reconhecer a importância da comunidade e ao acreditar que o processo de envelhecimento também pode ser experienciado como uma fase de dinamismo, de protagonismo e de muita diversão. Trata-se de um valor civilizacional negro-africano que, ao ser herdado e reelaborado no espaço urbano por uma guardiã das memórias da zona norte, constitui o néctar do vigor para os enfrentamentos que visam edificar um mundo democrático, sustentável e pluriversal.

\footnotetext{
${ }^{56}$ BHABHA, H. K. O local da cultura. Belo Horizonte: UFMG, 2003, p. 21.

${ }_{58}^{57}$ ACOSTA, op. cit., p. 95.

${ }^{58} \mathrm{O}$ termo aqui refere-se ao conceito cunhado por Boaventura de Sousa Santos. A ideia é valorizar a diversidade epistemológica do mundo, tendo em vista a dominação do Norte global que engendrou o colonialismo e o capitalismo, suprimindo muitas formas de saber de povos e culturas do sul, sob o ponto de vista geográfico e metafórico. Segundo o autor: "As epistemologias do Sul são o conjunto de intervenções epistemológicas que denunciam essa supressão, valorizam os saberes que resistiram com êxito e investigam as condições de um diálogo horizontal entre conhecimentos. A esse diálogo entre saberes chamamos ecologias de saberes". Cf. SANTOS, B. de S.; MENESES, M. P. Epistemologias do Sul. São Paulo: Cortez, 2010, p. 19.

${ }^{59}$ Segundo Milton Santos, o neoliberalismo seria "outro braço dessa globalização perversa", atuando de forma a enfraquecer e a "reduzir as possibilidades de afirmação das formas de viver cuja solidariedade é baseada na contiguidade, na vizinhança solidária, isto é, no território compartido". Cf. SANTOS, M. Da Totalidade ao Lugar. São Paulo: Edusp, 2005, p. 142.
} 


\section{Referências bibliográficas}

ACOSTA, A. O bem viver: uma oportunidade de imaginar outros mundos. São Paulo: Autonomia Literária, Elefante, 2016.

ALTUNA, R. R. de A. Cultura Tradicional Bantu. Luanda: Paulinas, 2014.

ANTONACCI, M. A. Memórias ancoradas em corpos negros. São Paulo: EDUC, 2014.

AZEVEDO, A. M. A memória musical de Geraldo Filme: os sambas e as micro-áfricas em São Paulo. 224 f. Tese (Doutorado em História) - Pontifícia Universidade Católica de São Paulo (PUC), Departamento de História, São Paulo, 2006.

BERNARDO, T. Memória em branco e negro: olhares sobre São Paulo. São Paulo: EDUC; Fundação Editora da UNESP, 1998.

BHABHA, H. K. O local da cultura. Belo Horizonte: UFMG, 2003.

CERTEAU, M. de. A invenção do cotidiano: 1. Artes de fazer. Petrópolis: Vozes, 1994.

EVARISTO, C. Olhos d'Água. Rio de Janeiro: Pallas, Fundação Biblioteca Nacional, 2016.

FERNANDES, A. P. da S. Candomblé de São Paulo: fundamentos e tensões de uma comunidade terreiro na metrópole.129 f. Dissertação (Mestrado em História) - Pontifícia Universidade Católica de São Paulo, São Paulo, 2017.

GILROY, P. O Atlântico Negro: modernidade e dupla consciência. São Paulo: Editora 34; Rio de Janeiro: Universidade Cândido Mendes; Centro de Estudos Afro-Asiáticos, 2001.

GLISSANT, É. Le discours antillais. Paris: Éditions du Seuil, 1981. . Introdução a uma poética da diversidade. Juiz de Fora: Editora UFJF, 2005.

GOMES, A. M. de A. "Melhor que o Mel, só o Céu": trauma intergeracional, complexo cultural e resiliência na diáspora africana (um estudo de caso do Quilombo do Mel da Pedreira, em Macapá, AP). 277f. Tese (Doutorado em Psicologia Clínica) - Pontifícia Universidade Católica de São Paulo, São Paulo, 2017.

KOSSOY, B. Fotografia \& História. São Paulo: Ateliê Editorial, 2001.

LEITE, F. Valores civilizatórios em sociedades negro-africanas. África: Revista do Centro de Estudos Africanos, USP, São Paulo, v. 1, p. 103-118, 1995/1996.

LOWY, M. O Narrador, In: BENJAMIN, Walter; HORKHEIMER, M.; ADORNO, T. W.; HABERMAS, J. Os pensadores. São Paulo: Abril cultural, 1980.

. Walter Benjamin: aviso de incêndio, uma leitura das teses "Sobre o conceito de história".

São Paulo: Boitempo, 2005.

MUNANGA, K.; GOMES, N. L. O negro no Brasil de hoje. São Paulo: Global, 2006.

RIBEIRO, R. Ì.; SÁLÀMì S. (King). Exu e a ordem do Universo. 2a. ed. São Paulo: Oduduwa, 2015.

ROLNIK, R. História urbana: História na cidade? In: FERNANDES, A.; GOMES, M. A. A. F. Cidade e história. Salvador: UFBA/ Faculdade de Arquitetura. Mestrado em Arquitetura e Urbanismo: Anpur, 1992.

Negros na cidade de São Paulo: presença invisível ou incômoda? Blog da Raquel Rolnik. 2017. Disponível em: <https://raquelrolnik.wordpress.com/2017/11/16/ negros-na-cidadede-sao-paulo-presenca-invisivel-ou-incomoda/>. Acesso em: $20 \mathrm{dez} .2017$.

SANTOS, A. S. A. A Dimensão Africana da Morte resgatada nas Irmandades Negras, Candomblé e Culto de Babá Egun. 244 f. Dissertação (Mestrado em Ciências Sociais) - Pontifícia Universidade Católica de São Paulo, Departamento de História, São Paulo, 1996.

SANTOS, B. de S.; MENESES, M. P. Epistemologias do Sul. São Paulo: Cortez, 2010.

SANTOS, Milton. O dinheiro e o território. GEOgraphia, Rio de Janeiro, ano 1, n. 1, p. 7-13, 1999. 
. Da Totalidade ao Lugar. São Paulo: Edusp, 2005.

SAVIETO, M. C. Catolicismos crioulizados: presença centro africana na região do Vale do Paraíba (SP). 118f. Dissertação (Mestrado em História) - Pontifícia Universidade Católica de São Paulo, Departamento de História, São Paulo, 2010.

SILVA, S. A. G. da. Negros em Guaianases: cultura e memória. 145 f. Dissertação (Mestrado em História) - Pontifícia Universidade Católica de São Paulo, Departamento de História, São Paulo, 2015.

SODRÉ, M. O terreiro e a cidade: a forma social negro-brasileira. Petrópolis: Vozes, 1988.

Claros e Escuros: identidade, povo e mídia no Brasil. 3a ed. Petrópolis: Vozes, 2015.

SWEET, J. H. Recriar África: cultura, parentesco e religião no mundo afro-português (1441-1770). Lisboa: Edições 70, 2007.

THOMPSON, R. F. Flash of the spirit: arte e filosofia africana e afro-americana. São Paulo: Museu Afro Brasil, 2011.

VOGEL, A.; MELLO, M. A. da S.; BARROS, J. F. P. de. A galinha d'angola: iniciação e identidade na cultura afro-brasileira. 3a. ed. Rio de Janeiro: Pallas, 2007.

\section{FONTES ORAIS}

Entrevista com a colaboradora/narradora Lucinda de Oliveira Marcelino, feita pelo autor em março de 2018.

Bruno Garcia dos Santos: é Mestre em História Social pela Pontifícia Universidade Católica de São Paulo (PUC-SP, 2018). Graduado em História (Licenciatura Plena) pela Universidade Estadual Paulista "Júlio de Mesquita Filho" (UNESP - Assis, 2010) com complementação curricular pela Université d'Avignon et des Pays de Vaucluse (UAPV, França, Região PACA - Provence, Alpes e Côte d'Azur, 2012). Pesquisador associado ao Grupo de Pesquisas e ao Centro de Estudos Culturais Africanos e da Diáspora da PUC-SP (CECAFRO). Filiado à Associação Brasileira de Pesquisadores Negros (ABPN). Atua como professor de História para alunos do Ensino Fundamental II e do Ensino Médio no colégio franco-brasileiro Lycée Pasteur - Unidade Vergueiro, em São Paulo (SP).

Amailton Magno Azevedo: é Professor do Programa de Estudos Pós Graduados em História e do Departamento de História da Faculdade de Ciências Sociais da Pontifícia Universidade Católica (PUC-SP). Possui graduação (Licenciatura e Bacharelado) em História pela Pontifícia Universidade Católica de São Paulo (1998), mestrado em História pela Pontifícia Universidade Católica de São Paulo (2000), doutorado em História pela Pontifícia Universidade Católica de São Paulo (2006) e Pós-doutorado pela Universidade do Texas em Austin (2011) com bolsa Capes. Desenvolveu pesquisa no Centro de Estudos Sociais da Universidade de Coimbra como Investigador convidado, em 2015, com auxílio à pesquisa da PUC/SP. Atua também como músico, tendo um disco gravado com o título Mundo Atlântico de 2004.

Artigo recebido para publicação em: Outubro de 2018.

Artigo aprovado para publicação em: Novembro de 2018. 